\title{
Environmental management and social marketing: a bibliometric analysis
}

\author{
Nataliia Letunovska ${ }^{1}$, Oleksii Lyuolyov $^{1}$, Tetyana Pimonenko ${ }^{1},{ }^{*}$ and Vadym Aleksandrov ${ }^{2}$ \\ ${ }^{1}$ Sumy State University, Department of Marketing, Ukraine \\ ${ }^{2}$ Sumy State University, Department of Finance and Entrepreneurship
}

\begin{abstract}
The primary purpose of this study is to analyze the structure and dynamics of scientific publications in the field of environmental management and social marketing in their relationship. The authors analyzed the original keywords in the field of environmental management and social marketing. They carried out the analysis of works in the Scopus scientometric database with the subsequent use of the analytics built in the database, as well as modern software for bibliometric analysis VOSviewer and SciMAT. This study included many papers published in seven languages in the field of economics and ecology (also taking into account works from the interdisciplinary category to more fully include all possible papers). Library analysis has revealed the popularity of the use of these categories with authors from different countries with research over the years. Listed six clusters of a collaboration of countries by co-authorship. The journals with the most massive citations of the analyzed categories are listed. There is a stable dynamics of the number of studies in these categories in the subperiod 2011-2016. However, current trends until 2020 show that the popularity of research, and most importantly, their relevance will remain at the peak in subsequent years. The study may be the basis for further research in the use of marketing principles to deepen the theory of environmental management.
\end{abstract}

\section{Introduction}

In the current realities of development, it is evident that the process of building the country must base on the coordination and harmonization of economic, social and environmental components in order to meet the needs of present and future generations. Among the areas of the healthy development of regions, a prominent place occupies the consideration of an environmental management concept. The new surge of interest in environmental issues in recent years is due to the growing demands of society for the social responsibility of enterprises. Existing domestic and foreign experience in implementing the concept of environmental management in companies focuses on promoting products with environmental characteristics, motivating businesses to implement a sound environmental policy in the production and sale of their products, informing the public about the importance of solving social and environmental problems due to the corporate product of a particular business entity, etc., which together is a direct subject of research in the field of marketing.

The authors consider the concept of environmental marketing in terms of two aspects: the formation of consumer environmental needs (production and promotion of environmental goods, services, recreational products) and a particular case of regional social marketing, which aims to analyze the impact of environmental initiatives on people as a subject region.
Living in an ecologically clean region, consumption of ecologically clean regions, sufficient level of treatment, rest in recreational places, responsible consumption - all these are areas where the ultimate goals of activities in the field of environmental management and a separate area of marketing - social.

Social marketing, both in practice and in theory, is related to environmental management. Companies that adhere to the principles of environmentally responsible activities fall into the category of "corporate social responsibility". These two interrelated categories aim at minimizing costs, strengthening the competitive position of the company, and building trusting relationships with contact audiences. Several advantages confirm the expediency of following the principles of socioenvironmental marketing and management. The concept of classifying consumers into black consumers, gray consumers, greyish consumers, and green consumers is becoming increasingly popular. The latter category one can characterize by high environmental awareness and is growing in quantitative terms.

In Ukraine, big business is the main subject of environmental initiatives. Positive environmental initiatives are often obligatory. The 2020 Environmental Performance Index (EPI) that provides a data-driven summary of the state of sustainability around the world. In 2020, Ukraine ranked 60th among 180 analyzed countries with a score of 49.5. However, in 2018 the score was higher -52.87 points [1]. The country still has a lot

* Corresponding author: n.letunovska@gmail.com 
to work. From these positions, a detailed bibliometric analysis of foreign and domestic works of scientists who have already paid attention to the study of these categories can be useful in developing a strategy for further action in the field of environmentally friendly production and consumption in Ukraine.

The purpose of this paper is to study and compare the category of social marketing and environmental management; analysis of subject areas of research in their evolution.

\section{Literature Review}

Systematization of scientific resources shows a significant basis for bibliometric analysis, as in the field of environmental management and social marketing, there is a sufficient number of works by scientists from different countries. Some authors devoted their researches to the study of various aspects of social marketing in the formation of healthy behavior of the population of a particular area [2-12]. Scientists Todua N., Jashi C. [13] describing the general problems of sustainable social development, consider the relevance of healthy eating among the population and the peculiarities of promoting this idea in general. At the same time, their research pays attention to the theoretical and practical aspects of social marketing. The article shows that in Georgia, there is a problem of creating a favorable environment for changing consumer behavior, promoting healthy eating. After all, the population of this country due to low incomes accustomed to eating food of low quality and questionable origin. At the same time, healthy food is not popular among the population because of the higher price. Therefore, one of the ways to solve this problem, the authors see in the use of advertising campaigns using elements of social marketing. Luca N.R., Hibbert S., and McDonald R. analyze how the concept of social marketing creates opportunities for change in the healthy behavior of individuals [14]. The study concludes that building relationships with the community provides an opportunity to respond promptly to social problems that arise in the environment. Lee N.R. [15] calls social marketing an essential tool in the management of a particular region.

Methodological approaches to social marketing can improve public health, warn the public about accidents, improve the financial and economic situation in the region, and so on. One can realize it through an influence on the behavior of citizens. The author proposes a ten-step program of action within the marketing approach using the most effective tools. McKinnon R.A., Siddiqi S.M., Chaloupka F.J. [16] consider certain aspects of social marketing as one of the tools of the economic impact on the environment for the formation of healthy behavior of the local community. Michaelidou, N., Reynolds, N., Greenacre, L. et al. [17] propose to study the behavior of respondents and their motivational attitudes to the proper environmental use of marketing principles and state that social marketing programs can positively influence the adaptation to the correct integrated environmental behavior.
Some authors base their researches on the use of marketing in the activities of social enterprises. Herbst J.M. [18] reveals the features of the strategic management of social enterprises to increase their social, economic, and environmental value. The author explores the features of social marketing as a driver to achieve the mission of sustainable development. He concluded that social enterprises attract the target audience, using a particular form of marketing - niche. Smith A.M., O'Sullivan T. [19] use marketing approaches, namely the formation of focus groups, to build a favorable environment in the workplace of organizations.

Some studies relate social marketing directly to the field of environmental management [20-31]. Wood M. $[32,33]$ analyzes the socio-economic prospects for the development of social marketing. The author argues that thanks to the tools of social marketing, it is possible to achieve significant changes in the environmental behavior of the environment. Naturally, he sees marketing as an opportunity for positive social change. McKenzie-Mohr D., Lee N.R., Schultz P.W. [34] describe in detail how socially oriented social marketing motivates to protect the environment, describing the experience of diverse environmental programs.

Due to the growing popularity of the Internet in society, a particular category of research is the work of scientists devoted to the application of the concept of social marketing in the electronic environment [35-38]. Pham H.C., Brennan L., Parker L, et al. [39] argue that a comprehensive study of changes in the behavior of users of the World Wide Web is an indispensable condition for cybersecurity. They pay attention to the study of $7 \mathrm{P}$ as an element of internal social marketing, which one can use to study the internal environment of the business entity to build a cybersecurity system in the future. Alhulail H., Dick M., Abareshi A. [40] exploring the features of Web 2.0, consider a new form of e-commerce - social commerce, focused on the technology of socially consumer-oriented content. They emphasize the need for marketing research of users in the electronic environment to form an effective loyalty system.

In some studies, scientists consider that social marketing is one of the approaches to the study of market performance in various industries [41-60]. For example, Ma L., Mulley C., Liu W. [61] state that the social marketing and construction industry are essential starting points for the formation of population preferences in travel. Kennedy A.-M. [62] introduces the concept of macro-social marketing as an integrated approach that has a positive impact on the macro-environment of the country and considers its essence on the example of antismoking campaigns. The same goes, for example, for marketing to promote environmentally friendly products, such as electric cars. Researches on the conditions of marketing activities in the field of health care occupy a special place. Koumpouros Y., Toulias T.L., Koumpouros N. [63] point to the enormous potential of social marketing in the health sector, confirming this assertion by surveying consumers and businesses to describe trends and perceptions. Kapoor A. and others [64] describe the broad scope of social marketing beyond traditional areas, noting insights into how one can 
use marketing to create a positive image of the environment $[65,66]$.

Regarding the national peculiarities of the use of social marketing in the field of environmental management, Rudawska E. [67] explores the peculiarities of the use of the concept of social marketing in the Polish market, in particular how Polish companies use marketing approaches to create a favorable microenvironment. Similar studies are from authors from other countries [68-70].

\section{Research methods}

To more clearly define the intersection of research areas, the authors of this research used the methods of modern bibliometric analysis [71]. They choose the scientometric base Scopus for analysis. The search was performed on the main keywords "social marketing", "environment", "environmental management". This search is made using the "title, abstract, keywords" option for a complete display of search results. The logical operator "AND" was used to display the results only in the presence of all search words [72]. The authors sorted the found resources in order to find only those that correspond to the field of research (socio-ecological-economic research).

For a more detailed analysis, including using the builtin Scopus database operator "Analyze search results" was used the combination of "social marketing" AND environment OR ecological OR protection OR pollution OR nature" with the logical connector "OR" to search for alternative keywords related to the research topic. At the next stage, the search results were visualized using modern software in the field of bibliometric analysis VOSviewer and SciMAT. VOSviewer software made it possible to single out research clusters according to selected criteria. SciMAT provided opportunities to visualize the number of documents developed by subperiods from the beginning of research in the field of environmental management and social marketing at their intersection.

\section{Results and Discussion}

Data processing made it possible to identify the TOP-8 most cited scientific papers that contribute to the development of research at the intersection of the subject of analysis (Table 1).

If to analyze the number of published articles in journals on selected topics, the leading publications are "Social Marketing Quarterly" (Sage Publishing, USA), "Journal of Social Marketing" (Emerald Group Publishing, UK), "Journal of Nonprofit and Public Sector Marketing” (Taylor \& Francis, UK).

The analysis of co-authored works within different countries makes it possible to determine which authors from which countries have made the most significant contribution to the study of research issues (Fig. 1). The largest cluster is occupied by authors from the USA, Great Britain, and Australia. Canada and South Africa are also among the top five. The number of publications per at least 3 per country was chosen as a clustering criterion.
The map visualizes six main clusters. The first provides an opportunity to see the collaboration between the United States, Israel, Mexico, and China, along with its Hong Kong Special Administrative Region.

Table 1. Journals with the highest citation of articles by search criteria.

\begin{tabular}{|c|c|c|c|}
\hline 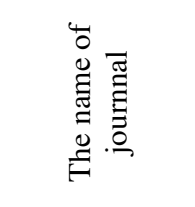 & 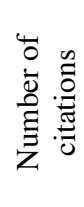 & 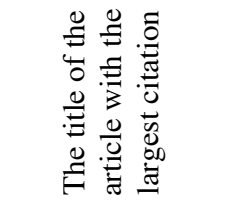 & 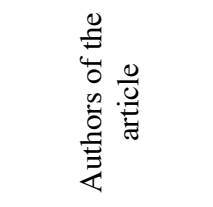 \\
\hline $\begin{array}{l}\text { Journal of } \\
\text { Marketing }\end{array}$ & 295 & $\begin{array}{l}\text { Reinventing } \\
\text { marketing to } \\
\text { manage the } \\
\text { environmental } \\
\text { imperative }\end{array}$ & Kotler P. \\
\hline $\begin{array}{l}\text { International } \\
\text { Journal of } \\
\text { Research in } \\
\text { Marketing }\end{array}$ & 137 & $\begin{array}{l}\text { Positive cueing: } \\
\text { Promoting } \\
\text { sustainable } \\
\text { consumer } \\
\text { behavior by } \\
\text { cueing common } \\
\text { environmental } \\
\text { behaviors as } \\
\text { environmental }\end{array}$ & $\begin{array}{c}\text { Cornelissen G., } \\
\text { Pandelaere M., } \\
\text { Warlop L., } \\
\text { Dewitte S. }\end{array}$ \\
\hline $\begin{array}{l}\text { Journal of } \\
\text { Social } \\
\text { Marketing }\end{array}$ & 103 & $\begin{array}{l}\text { An integrative } \\
\text { model for social } \\
\text { marketing }\end{array}$ & Lefebvre R.C. \\
\hline $\begin{array}{c}\text { Journal of } \\
\text { Public Policy } \\
\text { and Marketing }\end{array}$ & 86 & $\begin{array}{c}\text { Ethical } \\
\text { challenges of } \\
\text { social marketing }\end{array}$ & Brenkert G.G. \\
\hline $\begin{array}{c}\text { Journal of } \\
\text { Environ- } \\
\text { mental } \\
\text { Management }\end{array}$ & 71 & $\begin{array}{l}\text { Understanding } \\
\text { behavior to } \\
\text { inform water } \\
\text { supply } \\
\text { management in } \\
\text { developed } \\
\text { nations - A } \\
\text { review of } \\
\text { literature, } \\
\text { conceptual } \\
\text { model and } \\
\text { research agenda }\end{array}$ & $\begin{array}{c}\text { Hurlimann A., } \\
\text { Dolnicar S., } \\
\text { Meyer P. }\end{array}$ \\
\hline $\begin{array}{l}\text { European } \\
\text { Journal of } \\
\text { Marketing }\end{array}$ & 67 & $\begin{array}{c}\text { Social } \\
\text { marketing, } \\
\text { individual } \\
\text { responsibility } \\
\text { and the "culture } \\
\text { of intoxication" }\end{array}$ & $\begin{array}{c}\text { Szmigin I., } \\
\text { Bengry-Howell } \\
\text { A., } \\
\text { Griffin C., } \\
\text { Hackley C., } \\
\text { Mistral W. }\end{array}$ \\
\hline $\begin{array}{c}\text { Journal of } \\
\text { Marketing } \\
\text { Management }\end{array}$ & 55 & $\begin{array}{l}\text { Environmentall } \\
\text { y responsible } \\
\text { behaviour in the } \\
\text { workplace: An } \\
\text { internal social } \\
\text { marketing } \\
\text { approach } \\
\end{array}$ & $\begin{array}{l}\text { Smith A.M., } \\
\text { O'Sullivan T. }\end{array}$ \\
\hline $\begin{array}{l}\text { Journal of } \\
\text { Macro- } \\
\text { marketing }\end{array}$ & 45 & $\begin{array}{l}\text { Macro-social } \\
\text { Marketing }\end{array}$ & Kennedy A.-M. \\
\hline
\end{tabular}

The second cluster visualizes the fruitful collaboration of scientists from two powerful countries in this field, the United Kingdom and Canada. A third cluster separates cooperation between Australia, Taiwan, Portugal, and 
Iran. The fifth cluster shows cooperation between South Africa and countries such as Denmark and Sweden. The sixth cluster reflects the interaction between scientists from European countries (Germany, France, Spain).

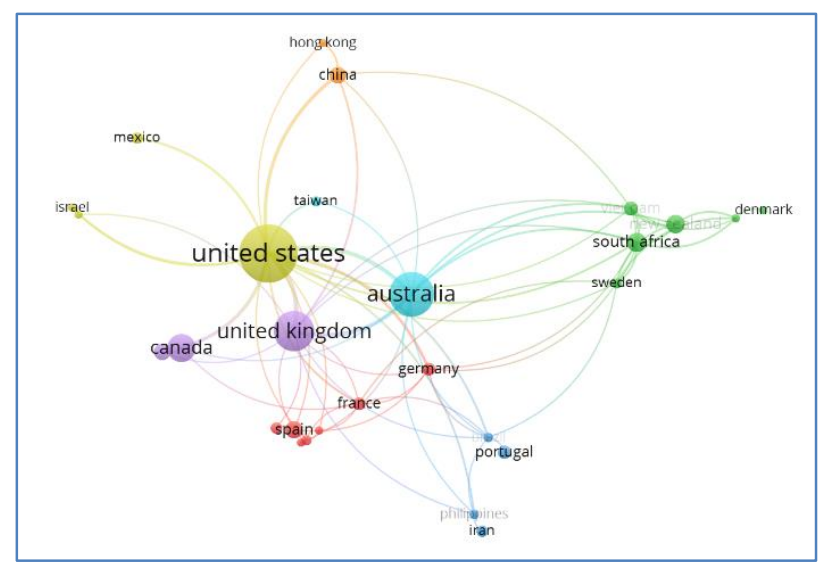

Fig. 1. Bibliometric analysis of published works by the country

Figure 2 shows the most cited works of scientists in the field of social marketing and environmental management since 1969. The most influential opinion is Kotler F., with a large number of citations. Works of the early 2000s are also gaining some popularity. Moreover, as shown in Fig. 3, from all spheres of the intersection of researches on social marketing, the big cluster of researches replenished this sphere at the intersection with research in the field of sustainable development (cluster of green color in Fig. 3).

Figure 4 shows the quantitative dynamics of publishing activity in the period from 1969 to 2020 (as of 11.05.2020). In the SciMAT program, this whole period is divided into subperiods. Furthermore, such analysis made it possible to trace a significant set of publishing activities of marketing research that intersects with environmental management in 2011-2016. The number of papers published in 2017-2020 shows that the popularity of research topics is not declining. Additional analysis of the frequency distribution of publishing activity by subperiods confirms the leading indicators of the subperiod 2011-2016 when the topic gradually gained considerable popularity.

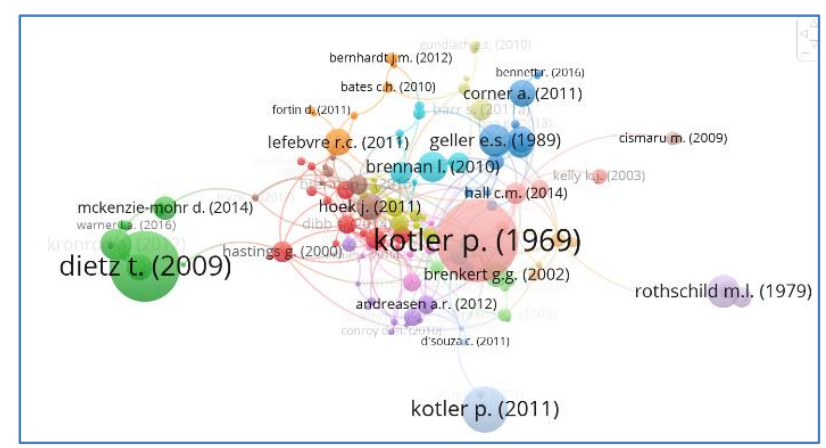

Fig. 2. The most cited scientists in the field of social marketing research in the Scopus database

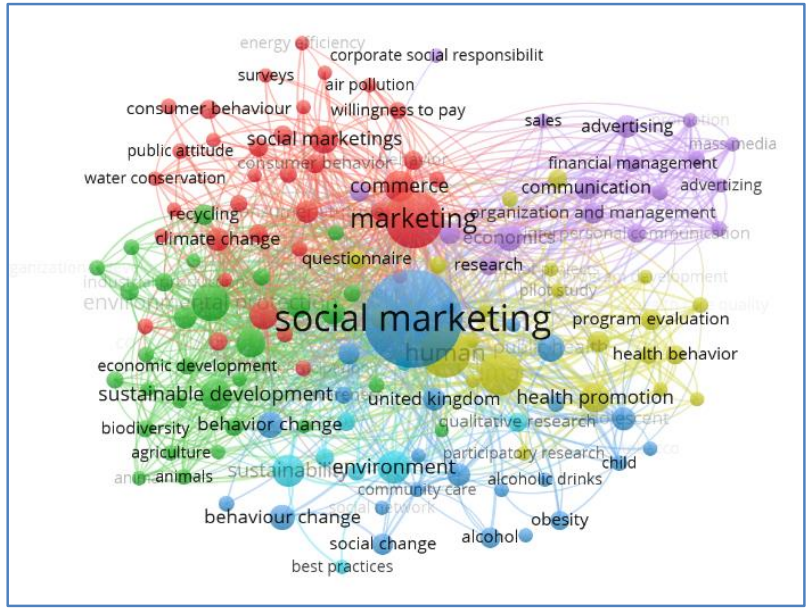

Fig. 3. Bibliometric map of keywords of researched works in the field of social marketing
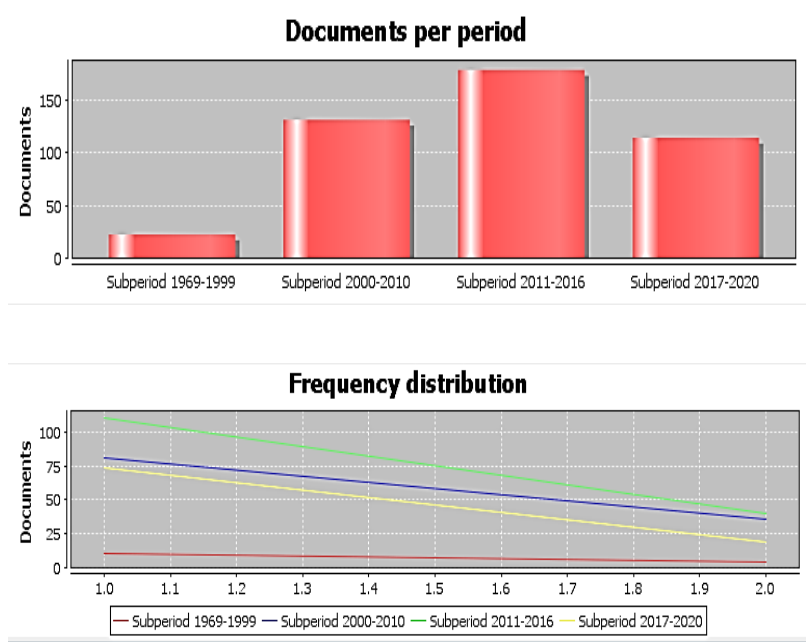

Fig. 4. Distribution of works on the topic of research by subperiods in the SciMAT program

The increase in the number of scientific works of scientists at the crossroads of research is due to the growing popularity of the concept of environmental marketing, which is a component of social marketing. Despite the variety of research areas, the central part is environmental and social marketing research, which aims to meet consumer needs so that the ecological balance of the environment is not disturbed and the health of the population is not harmed, while the losses of the subjects are reduced $[73,74]$.

\section{Conclusions}

The study analyzed the scientific works of the Scopus database in the field of social marketing and environmental management. The chosen field of research related to economics, business, and management with full coverage of all research from the middle of the twentieth century to the present date. The obtained results, analyzed in the software environment VOSviewer and SciMAT, indicate a positive trend in the number of publications and citations of works in the study area. 
The results of bibliometric analysis of the nationality of the authors of publications, the most cited names of scientists, and keywords in five clusters of studies are visualized. Cooperation in research on selected topics by authors from different countries with six separate clusters, one of which includes the work of Tielietov O.S., Letunovska N.Y. (2014). Organizational and economic mechanism of industrial enterprise social infrastructure management. Actual Problems of Economics, 160 (1), 329-337 [75] with two citations by authors from the Russian Federation. The results of the study can be useful for future researches in the field of social marketing and environmental management in their relationship with a detailed analysis of existing work in other influential scientometric databases.

\section{References}

1. Environmental Performance Index. URL: https:/epi.yale.edu/epi-results/2020/component/epi.

2. H. Dave. An inquiry on social issues - Part 1. Business Ethics and Leadership, 1(2), 78-87. Doi: 10.21272/bel.1(2).78-88.2017 (2017).

3. H. Dave. An Inquiry on Social Issues Part 2. Business Ethics and Leadership, 1(3), 45-63. DOI: 10.21272/bel.1(3).45-63.2017 (2017).

4. I. Pomianek. Historical and Contemporary Approaches to Entrepreneurship. Review of Polish Literature. Business Ethics and Leadership, 2(2), 7483. DOI: 10.21272/bel.2(2).74-83.2018 (2018).

5. Ch. Ahmad Rizwan, A. Semenog. Non-bank financial institutions activity in the context of economic growth: cross-country comparisons. Financial Markets, Institutions and Risks, 1(2), 3949. DOI: 10.21272/fmir.1(2).39-49.2017 (2017).

6. A. Boiko, I. Samusevych. The role of tax competition between the countries of the world and the features of determining the main tax competitors of Ukraine among the European countries. Financial Markets, Institutions and Risks, 1(1), 7279. http://doi.org/10.21272/fmir.1(1).72-79.2017 (2017).

7. H. Hadbaa, R. Boutti. Behavioral Biases Influencing the Decision Making of Portfolio Managers of Capital Securities and Traders in Morocco. Financial Markets, Institutions and Risks, 3(1), 92-105. DOI: http://doi.org/10.21272/fmir.3(1).18-29.2019 (2019).

8. S.N. Singh. Regional Disparity and Sustainable Development in NorthEastern States of India: A Policy Perspective. SocioEconomic Challenges, 2(2), 41-48. DOI: $10.21272 / \mathrm{sec} .2(2) .41-48.2018$ (2018).

9. U. Kolomiiets, Yu. Petrushenko. The human capital theory. Encouragement and criticism. SocioEconomic Challenges, 1(1), 7780. http://doi.org/10.21272/sec.2017.1-09 (2017).

10. Y. Khan. The Effectiveness of Entrepreneurial Activities for Economic Development: A Route to Innovation and Job Generation. SocioEconomic
Challenges, 2(2), 34-40. DOI: 10.21272/sec.2(2).3240.2018 (2018).

11. H. Dkhili. Environmental performance and institutions quality: evidence from developed and developing countries. Marketing and Management of Innovations, 333-244. http://doi.org/10.21272/mmi.2018.3-30 (2018).

12. A. Kwilinski. Mechanism of Modernization of Industrial Sphere of Industrial Enterprise in Accordance with Requirements of the Information Economy. Marketing and Management of Innovations, 4, 116-128. http://doi.org/10.21272/mmi.2018.4-11 (2018).

13. N. Todua, C. Jashi. Influence of Social Marketing on the Behavior of Georgian Consumers Regarding Healthy Nutrition. Bull. Georg. Natl. Acad. Sci, 12(2), 183-190 (2018).

14. N. R. Luca, S. Hibbert, S., R. McDonald. Understanding behaviour change in context: examining the role of midstream social marketing programmes. Sociology of health \& illness, 41(7), 1373-1395 (2019).

15. N. R. Lee. Policymaking for Citizen Behavior Change: A Social Marketing Approach. Routledge (2017).

16. R. A. McKinnon, S. M. Siddiqi, F. J. Chaloupka, L. Mancino, K. Prasad. Obesity-related policy/environmental interventions: a systematic review of economic analyses. American journal of preventive medicine, 50(4), 543-549 (2016).

17. N. Michaelidou, N. Reynolds, L. Greenacre, L. M. Hassan, J. D. Newton, F J. Newton et al. A cross-nationally validated decision-making model of environmental coaction. International Marketing Review, Vol. 32, No. 3/4, 350-365 (2015).

18. J. M. Herbst. Harnessing sustainable development from niche marketing and coopetition in social enterprises. Business Strategy \& Development, 2(3), 152-165 (2019).

19. A. M. Smith, T. O'Sullivan. Environmentally responsible behaviour in the workplace: An internal social marketing approach. Journal of Marketing Management, 28(3-4), 469-493 (2012).

20. L. Mura, M. Marchevska, M. Dubravska. Slovak Retail Business Across Panel Regression Model. Marketing and Management of Innovations, 4, 203211. http://doi.org/10.21272/mmi.2018.4-18 (2018).

21. T.A. Vasylyeva, S.A. Pryymenko. Environmental economic assessment of energy resources in the context of Ukraine's energy security. Actual Problems of Economics, 160(1), 252-260 (2014).

22. Y. Bilan, S. Lyeonov, T. Vasylieva, Y. Samusevych. Does tax competition for capital define entrepreneurship trends in Eastern Europe? Online Journal Modelling the New Europe, (27), 34-66 (2018).

23. Y. Bilan, T. Vasilyeva, O. Lyulyov, T. Pimonenko. EU vector of Ukraine development: 
Linking between macroeconomic stability and social progress. International Journal of Business and Society, 20(2), 433-450 (2019).

24. Y. Bilan, M. Brychko, A. Buriak, T. Vasilyeva. Financial, business and trust cycles: The issues of synchronization I [Ciklusi financiranja, poslovanja i povjerenja: pitanja za sinkronizaciju]. Zbornik Radova Ekonomskog Fakultet au Rijeci, 37(1), 113138 (2019).

25. G. Mentel, T. Vasilyeva, Y. Samusevych, S. Pryymenko. Regional differentiation of electricity prices: Social-equitable approach. International Journal of Environmental Technology and Management, 21(5-6), 354-372 (2018).

26. Y. Bilan, A.G. Raišienè, T. Vasilyeva, O. Lyulyov, T. Pimonenko. Public Governance efficiency and macroeconomic stability: Examining convergence of social and political determinants. Public Policy and Administration, 18(2), 241-255 (2019).

27. Y. Bilan, T. Vasilyeva, O. Kryklii, G. Shilimbetova. The creative industry as a factor in the development of the economy: Dissemination of european experience in the countries with economies in transition | [Kūrybinè industrija kaip ekonomikos plètros veiksnys: Europietiškosios patirties sklaida pereinamojo laikotarpio ekonomikos šalyse]. Creativity Studies, 12(1), 75-101 (2019).

28. T. Vasilyeva, S. Bilan, K. Bagmet, R. Seliga. R. Institutional development gap in the social sector: Crosscountry analysis, Economics and Sociology, 13(1), 271-294 (2020).

29. T. Vasilyeva, O. Kuzmenko, V. Bozhenko, O. Kolotilina. Assessment of the dynamics of bifurcation transformations in the economy. CEUR Workshop Proceedings, 2422, 134-146 (2019).

30. Y. Bilan, S. Lyeonov, N. Stoyanets, A. Vysochyna. The impact of environmental determinants of sustainable agriculture on country food security. International Journal of Environmental Technology and Management, 21(5-6), 289-305 (2018).

31. S. Lyeonov, T. Pimonenko, Y. Bilan, D. Štreimikiene, G. Mentel. Assessment of green investments' impact on sustainable development: Linking gross domestic product per capita, greenhouse gas emissions and renewable energy. Energies, 12(20), 3891 (2019).

32. M. Wood. Resilience research and social marketing: the route to sustainable behaviour change. Journal of Social Marketing, 9(1), 77-93 (2019).

33. M. Wood. Social marketing for social change. Social Marketing Quarterly, 22(2), 107-118 (2016).

34. D. McKenzie-Mohr, N. R. Lee, P. Kotler, W. Schultz. Social marketing to protect the environment: What works. Sage Publications (2011).

35. A. Teletov, S. Teletova, N. Letunovska. Use of language games in advertising texts as a creative approach in advertising management. Periodicals of
Engineering and Natural Sciences, 7(2), 458-462 (2019).

36. M.P. Bhandari. Green Web-II: Standards and perspectives from the IUCN program and policy development in environment conservation domain: A comparative study of India, Pakistan, Nepal, and Bangladesh. Green Web-II: Standards and Perspectives from the IUCN Program and Policy Development in Environment Conservation Domain: A Comparative Study of India, Pakistan, Nepal, and Bangladesh (2018).

37. A. Gren Ä, Y. Bilan, Y. Samusevych, A. Vysochyna. Drivers and inhibitors of entrepreneurship development in central and eastern European countries. Proceedings of the 33rd International Business Information Management Association Conference, IBIMA 2019: Education Excellence and Innovation Management through Vision 2020, 25362547 (2019).

38. Y. Bilan, Đž. Đšuzmenko, A. Boiko. Research on the impact of industry 4.0 on entrepreneurship in various countries worldwide. Proceedings of the 33rd International Business Information Management Association Conference, IBIMA 2019: Education Excellence and Innovation Management through Vision 2020, 2373-2384 (2019).

39. H. C. Pham, L. Brennan, L. Parker, T. N. Phan, I. Ulhaq, M. Z. Nkhoma, M. N. Nguyen (2019). Enhancing cyber security behavior: an internal social marketing approach. Information \& Computer Security. URL: https://www.emerald.com/insight /content/doi/10.1108/ICS-01-2019-0023/full/html (2019).

40. H. Alhulail, M. Dick, A. Abareshi. Factors that impact customers' loyalty to social commerce websites. In International Conference on Information Resources Management, 2018 Proceeding (Vol. 6) (2018).

41. O.V. Kozmenko, O.M. Pakhnenko. Financial methods of catastrophe risks management. Actual Problems of Economics, 118(4), 217-223 (2011).

42. N. Kostyuchenko, Y. Petrushenko, D. Smolennikov, Y. Danko. Community-based approach to local development as a basis for sustainable agriculture: Experience from Ukraine. International Journal of Agricultural Resources, Governance and Ecology. 11(2), 178-189 (2015).

43. Y.M. Petrushenko, N.M. Kostyuchenko, Y.I. Danko. Conceptual framework of local development financing in UNDP projects in Ukraine. Actual Problems of Economics, 159(9), 257-263 (2014).

44. V.Sukhonos, I. Makarenko. Sustainability reporting in the light of corporate social responsibility development: Economic \& Legal issues. Problems and Perspectives in Management, 15(1), 166-174 (2017).

45. O. Lyulyov, T. Pimonenko, N. Stoyanets, N. Letunovska. Sustainable development of agricultural sector: Democratic profile impact among 
developing countries. Research in World Economy, 10(4), 97-105 (2019).

46. O. Chygryn, T. Pimonenko, O. Luylyov, A. Goncharova. Green bonds like the incentive instrument for cleaner production at the government and corporate levels: Experience from EU to Ukraine. Journal of Environmental Management and Tourism, 9(7), 1443-1456 (2018).

47. Y. Yevdokimov, O. Chygryn, T. Pimonenko, O. Lyulyov. Biogas as an alternative energy resource for Ukrainian companies: EU experience. Innovative Marketing, 14(2), 7-15 (2018).

48. Y. Bilan, T. Pimonenko, L. Starchenko. Sustainable business models for innovation and success: Bibliometric analysis. E3S Web of Conferences, 159, 04037 (2020).

49. T. Pimonenko, Y. Bilan, J. Horák, L. Starchenko, W. Gajda. Green brand of companies and greenwashing under sustainable development goals. Sustainability (Switzerland), 12(4),1679 (2020).

50. L. Rui, L. Sineviciene, L. Melnyk, (...), O. Karintseva, O. Lyulyov. Economic and environmental convergence of transformation economy: The case of China. Problems and Perspectives in Management, 17(3), 233-241 (2019).

51. L.F. Sokolenko, I.V. Tiutiunyk, D.V. Leus. Ecological and economic security assessment in the system of regional environmental management: A case study of Ukraine. International Journal of Ecology and Development, 32(3), 27-35 (2017).

52. H. Shvindina. Coopetition as an emerging trend in research: Perspectives for safety \& security. Safety, 5(3), 61 (2019).

53. T. Bondar, Y. Matvieieva, I. Myroshnychenko. Assessment of the social, ecologic and economic development of machine building enterprises. Economic Annals-XXI, 7-8(1), 40-44 (2015).

54. O.A. Bilovodska, O.F. Gryshchenko, L.O. Syhyda. The marketing channel structure: A case of chemical industry company. Periodicals of Engineering and Natural Sciences, 7(2), 741-751 (2019).

55. L. Syhyda. Influence of enterprise's marketing environment on process of marketing distribution policy development. Economic Annals-XXI, 7-8(2), 28-32 (2013).

56. I. Serhii, G. Peresadko, , O. Pidlisna, E. Kovalenko. Corporate social responsibility in marketing researches: Literature review. Corporate Ownership and Control, 11(4 Continued 5), 499-503 (2014).

57. G.O. Peresadko, E.V. Kovalenko, L.A. Kulyk. Mechanisms of investing into innovative projects of enterprises. Actual Problems of Economics, 160(1), 184-187 (2014).

58. O.I. Karpishchenko, G.O. Peresadko, O.M. Olefirenko. Enterprise management systems: The case of "primary radiology group". Actual Problems of Economics, 154(4), 218-227 (2014).
59. O. Olefirenko. Theoretical and methodic grounds to identify potential sales markets of innovative production for Ukrainian machine building enterprises. Problems and Perspectives in Management, 13(4), 63-69 (2015).

60. M.P. Bhandari. Environmental Performance and Vulnerability to Climate Change: A Case Study of India, Nepal, Bangladesh and Pakistan. Climate Change Management, 149-167 (2013).

61. L. Ma, C. Mulley, W. Liu. Social marketing and the built environment: What matters for travel behaviour change?. Transportation, 44(5), 1147-1167 (2017).

62. A. M. Kennedy, A. Parsons. Macro-social marketing and social engineering: a systems approach. Journal of Social Marketing, 2(1), 37-51 (2012).

63. Y. Koumpouros, T.L. Toulias, , N. Koumpouros. The importance of patient engagement and the use of social media marketing in healthcare. Technology and Health Care, 23(4), 495-507 (2015).

64. A. Kapoor (Ed.). Dynamics of Competitive Advantage and Consumer Perception in Social Marketing. IGI Global (2013).

65. O. Rybina. Formation of the environmental marketing mechanism in the context of the sustainable development concept. Efektyvna ekonomika, $1, \quad$ URL: http://www.economy.nayka.com.ua/?op=1\&z=7594 DOI: 10.32702/2307-2105-2020.1.76 (2020).

66. O.A. Bilovodska, L.O. Sygyda. Improvement of theoretical-methodical approaches to the estimation of regional marketing attractiveness. Marketing and Management of Innovations, 1, 55-66 (2011).

67. E. Rudawska. Socially Responsible Marketing in Creating Value for Customers in the Polish Market. Challenges for the Trade of Central and Southeast Europe, 15, 73-94 (2014).

68. Y. Bilan, T. Vasilyeva, S. Lyeonov, K. Bagmet. Institutional complementarity for social and economic development. Business: theory and practice, 20, 103-115 (2019).

69. A. Kwilinski, V. Tkachenko, A. Kuzior. Transparent cognitive technologies to ensure sustainable society development. Journal of Security \& Sustainability Issues, 9(2), 561-570 (2019).

70. V. Babenko, M. Nehrey, E. Gaponova, N. Ryzhikova, E. Zaporozhets. Life expectancy of population of the country the role of health services effectiveness. Research in World Economy, 10(4), 86-91 (2019). https://doi.org/10.5430/rwe.v10n4p86

71. V. Panchenko, Yu. Harust, Ya. Us, O. Korobets, V. Pavlyk. Energy-Efficient Innovations: Marketing, Management and Law Supporting. Marketing and Management of Innovations, 1, 256-264. http://doi.org/10.21272/mmi.2020.1-21 (2020).

72. O. Chygryn, Y. Petrushenko, A. Vysochyna, A. Vorontsova. Assessment of Fiscal Decentralization Influence on Social and Economic 
Development. Montenegrin Journal of Economics, 14(4), 069-084 (2018).

73. O. S. Tielietov, N. Ye. Letunovska, M. V. Provozin. Social infrastructure of modern enterprises and territories. TOV Trytoriia (2019).

74. L. Yu. Saher, Yu. M. Melnyk, J. Niño-Amézquita. The problems of development of an effective management system of internal communications and ways to overcome them. Innovative management: theoretical, methodical and applied grounds. 1st edition, Prague Institute for Qualification Enhancement: Prague, 83-96 (2018).

75. O. S. Tielietov, N. Y. Letunovska. Organizational and economic mechanism of industrial enterprises social infrastructure management. Actual Problems of Economics, 160(1), 329-337 (2014). 